\title{
Fungal remains in cordaite (Cordaitales) leaves from the Upper Pennsylvanian of central France
}

\author{
Michael KRINGS, ThOMAS N. TAYLOR, NORA DOtZleR \& JeAn GaltieR
}

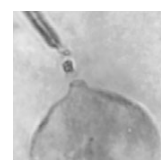

\begin{abstract}
Little is known to date regarding the organisms that colonized the leaves of Carboniferous plants. This is due to a number of factors, including how the leaves were preserved, prepared for examination, and analyzed. Nevertheless, it is becoming increasingly clear that Carboniferous leaves were habitats for a wide variety of fungi. This paper describes fungal remains in cordaite leaves from the Upper Pennsylvanian Grand-Croix cherts in France. Within the intercellular system of the mesophyll occur intercalary and terminal swellings produced from an elaborate system of tenuous hyphae/filaments, as well as isolated putative (zoo-)sporangia and clusters of small unicells. Other fungal remains occur in bundle sheath cells. Although the systematic affinities of the fungi currently remain unknown, documenting their existence contributes to our understanding of the multiple levels of biological association and interaction that shaped the Carboniferous terrestrial ecosystems. - Key words: bundle sheath, Carboniferous, chert, fossil fungi, Grand-Croix, spongy parenchyma.
\end{abstract}

KRINGS, M., TAYLOR, T.N., DOTZLER, N. \& GALTIER, J. 2011. Fungal remains in cordaite (Cordaitales) leaves from the Upper Pennsylvanian of central France. Bulletin of Geosciences 86(4), 777-784 (2 figures). Czech Geological Survey, Prague. ISSN 1214-1119. Manuscript received April 12, 2011; accepted in revised form July 28, 2011; published online August 5, 2011; issued November 16, 2011.

\begin{abstract}
Michael Krings, Nora Dotzler, Department für Geo- und Umweltwissenschaften, Paläontologie und Geobiologie, Ludwig-Maximilians-Universität, and Bayerische Staatssammlung für Paläontologie und Geologie, Richard-WagnerStraße 10,80333 Munich, Germany; m.krings@lrz.uni-muenchen.de, hase42@gmx.net•Michael Krings \& Thomas N. Taylor, Department of Ecology and Evolutionary Biology, and Natural History Museum and Biodiversity Research Center, The University of Kansas, Lawrence KS 66045-7534, U.S.A.; tntaylor@ku.edu • Jean Galtier, AMAP, UMR 5120 CNRS, CIRAD TA A-51/PS2, Boulevard de la Lironde, 34398 Montpellier, France; jean.galtier@ cirad.fr
\end{abstract}

Cordaites are one of the most conspicuous elements in Late Pennsylvanian and Early Permian tropical forest ecosystems (Barthel 1976, Šimůnek 2000, Martín-Closas \& Galtier 2005). These plants, which are thought to represent a grade of evolution leading to modern conifers (e.g., Hilton \& Bateman 2006, Gomankov 2009), were up to $45 \mathrm{~m}$ tall; the above-ground portion included massive, woody trunks and a crown of elongate, strap-shaped leaves, some of which were up to $70 \mathrm{~cm}$ in length (Šimůnek \& Libertín 2006). Extending the length of the leaves are alternating bands of fibers and vascular bundles; their spacing and arrangement, together with leaf shape and epidermal anatomy, have been used to distinguish various leaf morphospecies (e.g., Harms \& Leisman 1961, Šimůnek 2007). Recent research suggests that the cordaites were wellestablished in several different environments, including poorly to well drained mineral soils, as well as coastal and upland settings (Falcon-Lang 2003, 2005; Falcon-Lang \& Bashforth 2004, 2005).

Although much is known about the biology and ecology of cordaites based on innumerable impression/compression specimens and permineralizations (Taylor et al. 2009), one aspect that rarely is addressed concerns the various associations and interactions of these plants with other groups of organisms. For example, Cichan \& Taylor (1982) described arthropod borings in the woody cordaitalean root Premnoxylon, and Strullu-Derrien et al. (2009) reported on arbuscular mycorrhizal fungi in Radiculites-type rootlets. While these associations have been demonstrated in secondary wood and the below-ground parts of the plants, we are unaware of any clearly defined evidence of associations of other organisms, especially arthropods and microorganisms, with the leaves of cordaites, with the possible exception of a few questionable structures interpreted as bite marks (Müller 1982) and leaf mines (Labandeira 1998). This is surprising since most cordaite leaves are quite large, and thus appear to have represented particularly suitable sites for arthropod herbivory and colonization by biotrophic and saprotrophic epiphyllous and endophytic microorganisms.

In this paper we report on the occurrence of fungi in structurally preserved cordaite leaves from the Upper Pennsylvanian (Carboniferous) Grand-Croix cherts of central France. The fungi occur within the intercellular system 
of the mesophyll, as well as in the parenchymatous sheaths that surround the vascular bundles. This discovery provides the first evidence of cordaite leaves colonized by fungi. Moreover, the occurrence of some of the fungi is restricted to well-defined areas within the leaves, which may suggest that these organisms were biotrophs.

\section{Material and methods}

The thin sections containing the fragments of cordaite leaves come from the Grand-Croix cherts, which occur in the eastern part of the Saint-Étienne Basin in central France. They occur within the so-called "Poudingue mosaïque" at several localities in the vicinity of the city of La Grand-Croix (Galtier 2008). The stratigraphic provenance and age of the Grand-Croix cherts are difficult to resolve, but generally they are interpreted as belonging either to the terminal portion of the Rive de Gier Formation (dated as Stephanian A; see Vetter 1971), or to the sediments overlying the Rive de Gier Formation, which have been dated as earliest Stephanian B (Pruvost 1947). Regardless of the age, the cherts are probably reworked, and therefore may be slightly older, i.e. late Stephanian A (equivalent to the late Barruelian) in age (Doubinger et al. 1995).

The infected leaf fragments are contained in two different thin sections of Grand-Croix chert deposited in the paleobotanical collection of the Swedish Museum of Natural History (Naturhistoriska riksmuseet) in Stockholm (Sweden) under acquisition numbers S003419-05 (Fig. 1) and S003409-06 (Fig. 2). The fungi were examined in transmitted light, with digital images captured with a Leica DFC 480 digital camera and processed in Adobe Photoshop.

\section{Description}

The infected leaf fragments are represented by mm-sized pieces of leaf tissue. One fragment appears in a longitudial (radial) section (Fig. 1), the other in a paradermal (sagittal) plane (Fig. 2). The fragments are identified as cordaite leaves based on internal structure (e.g., compare Figs 1A, 2A with Harms \& Leisman 1961, pl. 126, figs 1, 3), as well as the morphology and arrangement of stomata (Fig. 2B). Be- cause we are dealing with isolated leaf fragments, and thus cannot determine whether both fragments come from the same type (i.e. morphospecies) of cordaite leaf, we will describe the fungal remains from each leaf piece separately under the designation leaffragment 1 and leaffragment 2 .

\section{Leaf fragment 1 (Fig. 1)}

This fragment of leaf (Fig. 1A) is approximately $20 \mathrm{~mm}$ long and $0.5 \mathrm{~mm}$ wide. Within the leaf are several different types of fungal remains, with the most conspicuous being a mycelium of tenuous hyphae or filaments (each of which up to $2 \mu \mathrm{m}$ in diameter) producing both intercalary and terminal swellings. This mycelium occurs exclusively within the intercellular system of the mesophyll (Fig. 1B, C), most frequently in the large intercellular spaces of the spongy parenchyma (Fig. 1D). The swellings range from spherical to slightly spindle-shaped and are up to $18 \mu \mathrm{m}$ in diameter. The wall is thin, unornamented, and lacks any observable exit pore or tube (Fig. 1E). What is unusual about this fossil fungus is that the swellings and hyphae/filaments appear to have been preserved in a different state of development. In general, the swellings show little evidence of decay. The hyphae/filaments are preserved in place and in a configuration that indicates their exact relationship with the swellings during life (e.g., Fig. 1D, E). However, they appear to have been in an advanced state of disintegration at the time of preservation. This is evidenced by the opaqueness of most of the hyphae/filaments (Fig. 1E). Moreover, almost all hyphae/filaments are not represented by continuous threads, but rather consist of irregular segments that, although dissociated, are still aligned to reflect hyphae/filaments. While most of the swellings occur freely within the intercellular spaces, some are attached to the outer surfaces of parenchyma cells (Fig. 1F).

In addition to this conspicuous fungus, there are several other types of fungal remains within the intercellular system. One of these consists of more or less spherical structures up to $18 \mu \mathrm{m}$ in diameter that are attached to outer host cell wall surfaces, preferably to outer surfaces of bundle sheath cells (Fig. 1G). These spherical structures are relatively thin-walled, and some distinctly ornamented by discontinuous and irregularly distributed ridges (Fig. 1H). While most of the spheres are sessile, some possess a short,

Figure 1. Leaf fragment 1. $\bullet$ A - longitudinal (radial) cross section of cordaite leaf, showing mesophyll and part of a bundle sheath (to the right of image); bar $=100 \mu \mathrm{m} . \bullet \mathrm{B}, \mathrm{C}-$ mycelium within intercellular system of mesophyll; bar $=50 \mu \mathrm{m}$. $\bullet \mathrm{D}-$ detail of Fig. $1 \mathrm{C}$, showing mycelium with intercalary and terminal spherical structures; bar $=20 \mu \mathrm{m}$. $\bullet$ E - spherical structures; note irregular segments that although disassociated are still aligned to reflect hyphae/filaments; bar $=10 \mu \mathrm{m}$. $\bullet \mathrm{F}$ - spherical structure with dissociated hyphae/filaments at both ends; bar $=10 \mu \mathrm{m}$. $\bullet \mathrm{G}-\mathrm{spherical}$ structures attached to outer surfaces of bundle sheath cells; bar $=50 \mu \mathrm{m} . \bullet \mathrm{H}-$ detail of spherical structure ornamentation; bar $=10 \mu \mathrm{m}$. $\bullet \mathrm{I}-$ stalked spherical structures; bar $=10 \mu \mathrm{m} . \cdot \mathrm{J}-$ spheres on outer host cell surface; note basal mycelium extending out on host cell surface; bar $=30 \mu \mathrm{m}$. $\bullet \mathrm{K}-\mathrm{spherical}$ structure with what appears to be an infection peg (arrow); bar $=10 \mu \mathrm{m} . \bullet \mathrm{L}-$ putative mycoparasite (arrow) attached to spherical structure; bar $=10 \mu \mathrm{m}$. 

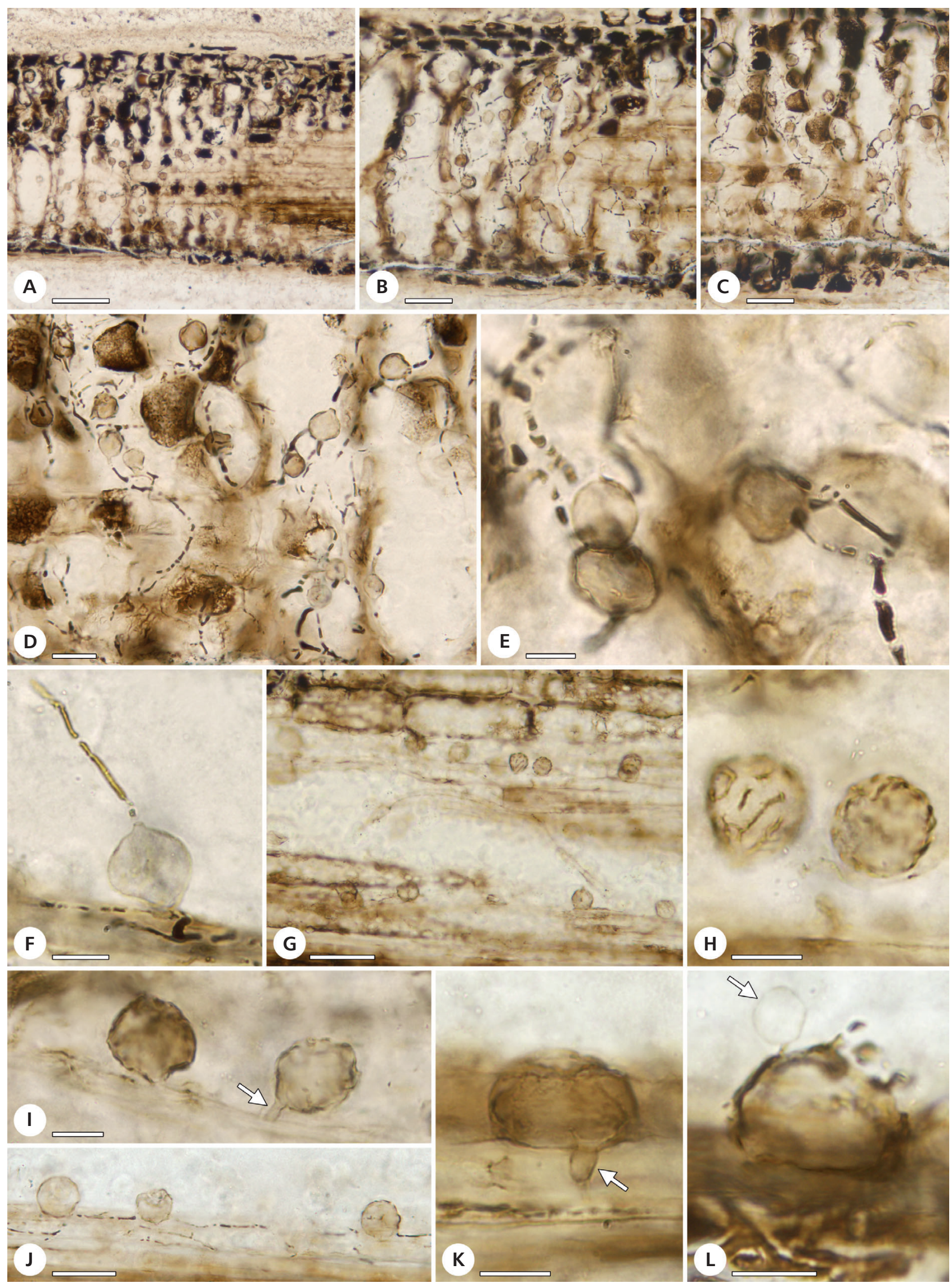

4

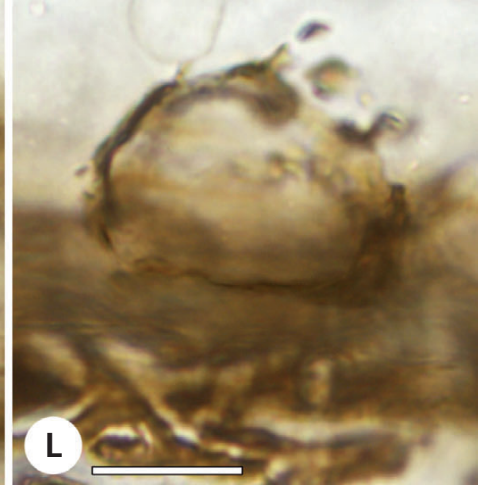


narrow stalk (arrow in Fig. 1I). Both unornamented and ornamented spheres arise from, or give rise to, delicate mycelia extending out on the outer surface of the host cells to which the spheres are attached (Fig. 1J). These mycelia are identical in appearance to that seen in the intercellular system; the individual hyphae/filaments, however, are slightly narrower, i.e. up to $1 \mu \mathrm{m}$ in diameter. We are unsure as to whether this type of fungus is simply a different form of the type that occurs freely in the intercellular system, or represents some other fungus, or is perhaps a different developmental stage of the form described above.

Still other spherical structures attached to outer host cell wall surfaces are distinctly larger (up to $25 \mu \mathrm{m}$ in diameter) and have more opaque walls (Fig. 1K, L). Some of these latter spheres show what appears to be an infection peg penetrating into the lumen of the host cell (arrow in Fig. $1 \mathrm{~K}$ ). In one example there is a small, thin-walled spherule attached to one of the larger spheres (arrow in Fig. 1L).

\section{Leaf fragment 2 (Fig. 2)}

This fragment of leaf (Fig. 2A) measures $1.3 \times 7 \mathrm{~mm}$, and shows several tissues of the leaf that are not well recognizable in leaf fragment 1 [e.g., the stomatiferous epidermis (Fig. 2B) and subepidermal tissue (Fig. 2C)]. Fungal remains within this leaf (Fig. 2D, E) consist of spherical to pyriform or elliptical structures up to $17 \mu \mathrm{m}$ in diameter that may be free within the intercellular spaces of the mesophyll or attached to the outer wall surfaces of mesophyll cells (Fig. 2F, G, J-N). The wall of some of these spheres appears double (e.g., Fig. 2K), suggesting that they contain a slightly smaller inner body, which may represent a spore or simply a preservational artifact caused by shrinkage of the lumen and separation of the wall layers. It is also possible, however, that the wall of the spheres is composed of different wall components giving the impression of a double wall. Some of the spherical structures have 1-2 hyphal/filament fragments attached, indicating both intercalary and terminal development; an elaborate mycelium like that seen in the intercellular system of leaf fragment 1 , however, is not recognizable. It is interesting to note that spheres are more frequent toward the margin of the intercostal fields (Fig. 2F, G), and in these regions the fungi usually occupy the corners of the intercellular spaces that are directly adja- cent to the bundle sheaths. In some instances (e.g., Fig. 2J) the spheres in the corners appear to be surrounded by a diffuse, translucent investment. Many of the spheres contain slightly pointed or irregularly elongate protrusions (Fig. 2G, M, N) that may be more opaque; some of the protrusions appear to be separated from the main sphere by a septum (arrow in Fig. 2M).

In one area of the leaf fragment, structures similar to those that are present in the intercellular system occur densely clustered within the parenchymatous cells of a bundle sheath (arrows in Fig. 2C; Fig. 2O-Q), in the outer cell layer directly adjacent to the subepidermal tissues and spongy parenchyma. Attachment to subtending hyphae in these clusters was not observed, and thus also infection pathways could not be determined. Fig. 2H, I shows clusters of 2-8 minute, thin-walled spherical unicells up to $5 \mu \mathrm{m}$ in diameter, each of which is surrounded by what appears to be a translucent sheath. The arrangement of the components in several-cell units is always regular and consistent.

\section{Discussion}

Despite the fact that there is an increasing number of records of well preserved Carboniferous fungi (e.g., Taylor et al. 1994; Krings et al. 2009a-c, 2010a-c, 2011; StrulluDerrien et al. 2009, 2011), very few of these are reports on fungi associated with leaves of vascular plants. Moreover, these few occurrences are usually based on single reports (e.g., Oliver 1903, Barthel 1961, Krings 2001, Krings et al. 2009b, Hübers et al. 2011), rather than including several infected specimens of the same leaf type that could provide a more inclusive understanding of the fungi (Krings et al. 2010c). This is puzzeling since leaf endophytes represent a significant proportion of today's total fungal diversity (Petrini 1991, Rodriguez et al. 2009), and all major groups of fungi were in existence by the Carboniferous (Blair 2009). The fungal remains in cordaite leaves from Grand-Croix are special among the leaf-inhabiting fungi known from the Carboniferous. Firstly, they do not represent single occurrences, but rather entire assemblages of morphologically and in part spatially distinct fungal remains. Secondly, the assemblages represent the first documented evidence of fungi colonizing cordaite leaves, which are distinct among the leaf types occurring in Carboniferous coal swamp

Figure 2. Leaffragment 2. $\bullet$ A - slightly oblique paradermal (sagittal) section of cordaite leaf, showing vascular bundles and mesophyll; bar $=500 \mu$ m. - B - detail of epidermis (with stomata) and subepidermal tissue; bar $=100 \mu \mathrm{m}$. $\bullet \mathrm{C}$ - detail of subepidermal tissue; note clusters of fungal remains in bundle sheath cells (arrows); bar $=50 \mu \mathrm{m}$. $\bullet \mathrm{D}, \mathrm{E}-$ fungal remains in intercellular system of spongy parenchyma; bars $=50 \mu \mathrm{m}$. $\bullet \mathrm{F}, \mathrm{G}-\mathrm{spherical}$ structures in intercellular spaces adjacent to bundle sheath; bars $=10 \mu \mathrm{m}$. $\bullet \mathrm{H}, \mathrm{I}$ - pair and small cluster of thin-walled unicells, each surrounded by what appears to be a translucent sheath; bars $=5 \mu \mathrm{m}$. $\bullet \mathrm{J}-\mathrm{N}-$ spherical structures in intercellular system of spongy parenchyma; arrow in Fig. $2 \mathrm{M}$ indicates septum at the base of protrusion; bars $=10 \mu \mathrm{m}$. $\bullet \mathrm{O}-\mathrm{Q}-$ clusters of spherical structures in bundle sheath cells (see arrows in Fig. $2 \mathrm{C}$ ); bars $=20 \mu \mathrm{m}$. 


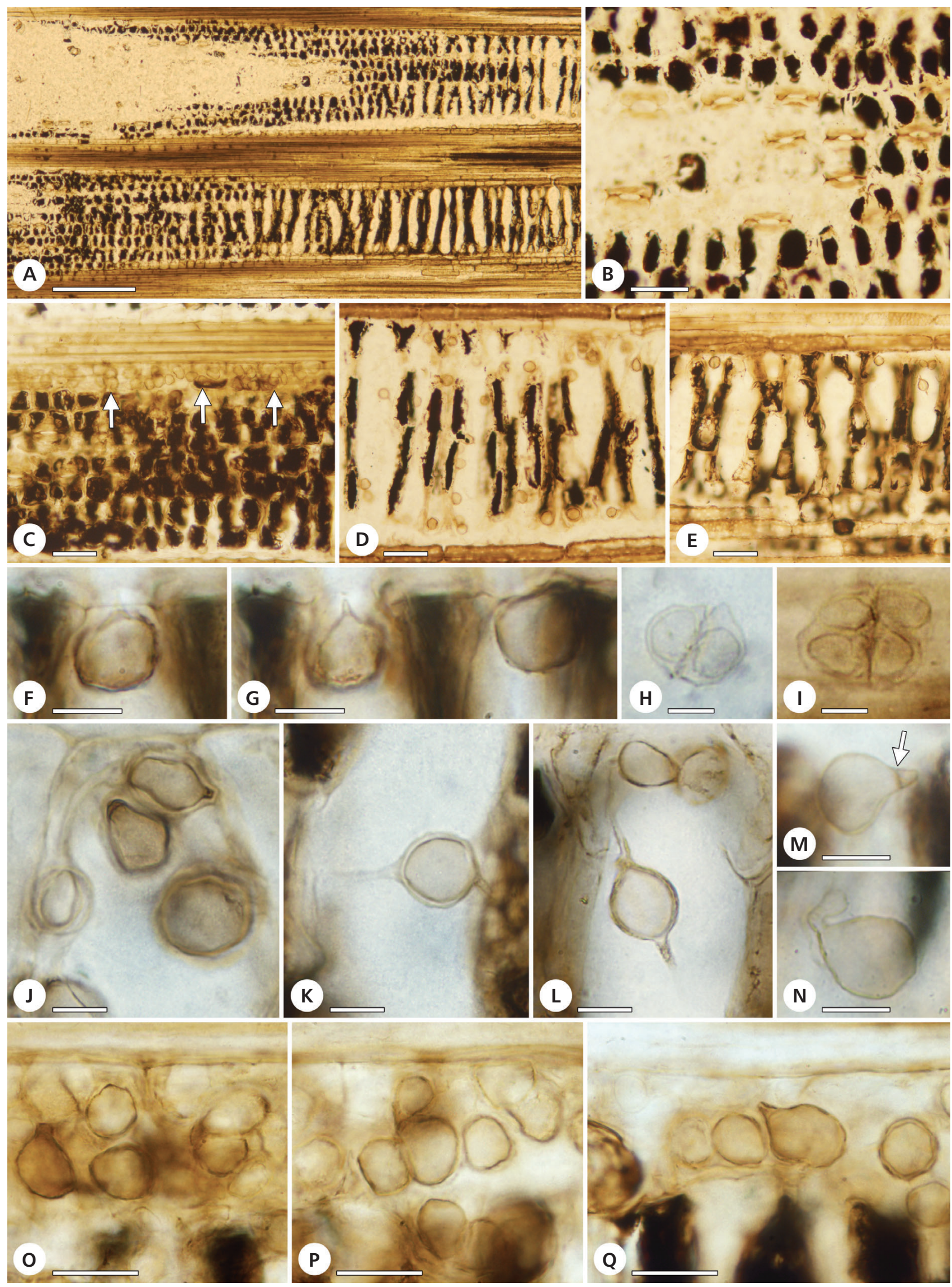


plants (i.e. microphylls and compound fronds), and thus may have provided some special features for colonization.

We are uncertain as to what major groups the fungi represented by the remains in these two cordaite leaf fragments may belong to. Moreover, it is difficult to identify biological species because the different types of fungal remains within the leaves may not all represent separate species, but rather different life history stages of the same organism. It is also possible that the individual types of remains each represent several morphologically similar species. Unfortunately, this lack of preciseness is an inherent problem in paleomycology that has been detailed previously (Sherwood-Pike 1991, Krings et al. 2010c), and thus need not to be addressed here again. The fungal remains in leaffragment 1 based on their overall morphology might represent rhizomycelial systems and zoosporangia of monocentric (e.g., Fig. 1K, L) and polycentric (e.g., Fig. 1D, J) chytrids (Chytridiomycota) (see Karling 1977). However, affinities with other groups of Fungi or fungus-like microorganisms (e.g., Hyphochytridiomycota, Peronosporomycetes) cannot be ruled out. The same is true of the intercalary and terminal spherical structures occurring in the intercellular system of leaf fragment 2 (e.g., Fig. 2F, G, $\mathrm{J}-\mathrm{N})$. The clusters of intracellular spheres illustrated in Fig. 2O-Q resemble chytrid-like organisms described previously from Grand-Croix (compare Fig. 2C, O-Q with Krings et al. 2009c, pl. I, fig. 5a-c). The latter occur in cortical cells of a specimen of the zygopteridalean reproductive structure Biscalitheca cf. musata. The affinities of the pairs and clusters of small unicells illustrated in Fig. 2H, I remain elusive, and could include algae, cyanobacteria, and some fungal structures. It is interesting to note that similar structures have been reported from the Lower Devonian Rhynie chert where they occur in the rhizome cortex of the early land plant Horneophyton lignieri (Taylor et al. 1992, figs 1-12) and from Viséan (Middle Mississippian) cherts of France where they occur freely in the chert matrix (Krings et al. 2009a, pl. III, figs 4-6). The Rhynie and Visean unicells, however, are larger (i.e. $>10 \mu \mathrm{m}$ in diameter) and distinguished from the Grand-Croix fossils by the presence of a short discharge tube extending from the unicells. The Visean specimens have been interpreted as zoosporangia of an endobiotic chytrid that formed holocarpic thalli in host cells (Krings et al. 2009a).

Another interesting but difficult question concerns the timing of when the fungi entered and colonized the host leaves. In general, this question relates to whether the leaves were alive and fully intact when colonization by the fungi occurred, or had become moribund but were still attached to the tree, or had already been abscised and were lying on the forest floor. Based on the conditions of the interior tissues, especially the spongy parenchyma (Figs 1A, B, 2A, D, E), one may suggest that the leaves were alive at the time of colonization. Moreover, two of the fungi in leaffragment 1 (Fig. 1D, J) appear in a life history stage in which sporangia/propagules have been produced, but the producing hyphal/filament system has not yet completely undergone disintegration. This sequence of events suggests that the time of infection predates the condition at the time of preservation by some time. Arguing in favor of colonization during the lifetime of the leaves is also the occurrence of intracellular clusters of fungal remains that are restricted to parenchymatous bundle sheath cells (Fig. 2C, O-Q). On the other hand, the infected fragments represent minute portions of usually rather large leaves, and it is reasonable to assume that this fragmentation was the result of considerable mechanical forces that occurred prior to fossilization. If this is accurate then one might challenge the assumption that infection occurred during the lifetime of the leaf, because the delicate hyphal/filament systems present in leaf fragment 1 (Fig. 1B-D, J) do not show evidence of mechanical distortion, which would certainly have occurred if the fungi were present when the leaf became fragmented. This line of reasoning rather suggests that colonization occurred after the leaf abscised from the parent plant and became fragmented, and thus that the fungi represent saprotrophs. Compounding the determination of the timing of when a fungus actually entered its host plant with regard to the Grand-Croix fossils is a general lack of information on the sequence of events and timing of precisely when silicification occurred.

In spite of the inherent problems, the discovery of fungi in cordaite leaves has scientific merit. Firstly, it provides a general framework with which to consider the utilization of microhabitats by fungi during the Carboniferous. In this context it will be interesting to see if morphologically similar types of fungi were generalists and colonized the leaves of different plants, and/or whether these particular types of fungi were general in overall preference for plant organs (e.g., roots, shoot axes, leaves, reproductive structures). Secondly, despite the lack of information on the biological affinities of the fungi, it is possible to trace certain features of how the fungi functioned and interacted with their host. For example, the hyphal/filament network of the fungal morphotype shown in Fig. 1B-E is in the process of disintegration, while the spherical structures formed by this network are consistently intact. This suggests to us that in this particular fungus the mycelium had completed its function at the time of fossilization. Moreover, the spatial arrangement of the fungal remains within the leaves suggests that the spongy parenchyma may have represented a particularly suitable site for fungal colonization, perhaps related to the presence of large intercellular spaces. As a result, the fungal remains reported in cordaite leaf fragments from Grand-Croix expand our knowledge of both the fungi and what kinds of plant tissues they inhabited in the Carboniferous. Reports such as this represent initial steps in better understanding of the Carboniferous swamp forest 
communities and the multiple levels of biological association and interaction that shaped these complex ecosystems some 300 Ma ago.

\section{Acknowledgments}

This study was supported by funds from the National Science Foundation (EAR-0949947 to T.N.T. and M.K.) and the Alexander von Humboldt-Foundation (V-3.FLF-DEU/1064359 to M.K.). N.D. acknowledges financial support for her project SE-TAF-508 performed at the Swedish Museum of Natural History within SYNTHESYS. SYNTHESYS receives funding from the European Community - Research Infrastructure Action under the FP7 "Capacities" Specific Programme. We thank Else-Marie Friis and Christian Pott (Stockholm, Sweden) for making the thin-sections available. The paper greatly benefited from the constructive comments and suggestions of Christine Strullu-Derrien and an anonymous reviewer.

\section{References}

BARTHel, M. 1961. Ein Pilzrest aus dem Saarkarbon. Geologie $10,856-857$.

BARTHEL, M. 1976. Die Rotliegendflora Sachsens. Abhandlungen des Staatlichen Museums für Mineralogie und Geologie zu Dresden 24, 1-190.

BLAIR, J.E. 2009. Fungi, 215-219. In HedGes, S.B. \& KUMAR, S. (eds) The Timetree of Life. Oxford University Press, New York, NY.

Cichan, M.A. \& TAYLOR, T.N. 1982. Wood-borings in Premnoxylon: plant-animal interactions in the Carboniferous. Palaeogeography, Palaeoclimatology, Palaeoecology 39, 123-127. DOI 10.1016/0031-0182(82)90075-X

DOUBinger, J., VetTER, P., LANGiAuX, J., GALTIER, J. \& BROUTIN, J. 1995. La flore fossile du bassin houiller de SaintEtienne. Mémoirs du Museum national d'Histoire naturelle, Paris 164, 1-357.

FALCON-LANG, H.J. 2003. Anatomically-preserved cordaitalean trees from a dryland alluvial plain setting, Joggins, Nova Scotia. Atlantic Geology 39, 259-265.

FALCON-LANG, H.J. 2005. Small cordaitalean trees in a marineinfluenced coastal habitat in the Pennsylvanian Joggins Formation, Nova Scotia. Journal of the Geological Society of London 162, 485-500. DOI 10.1144/0016-764904-080

FAlCON-LANG, H.J. \& BASHFORTH, A.R. 2004. Pennsylvanian uplands were forested by giant cordaitalean trees. Geology 32, 417-420. DOI 10.1130/G20371.1

FALCON-LANG, H.J. \& BASHFORTH, A.R. 2005. Morphology, anatomy, and upland ecology of large cordaitalean trees from the Middle Pennsylvanian of Newfoundland. Review of Palaeobotany and Palynology 135, 223-243. DOI 10.1016/j.revpalbo.2005.04.001

GALtiER, J. 2008. A new look at the permineralized flora of Grand-Croix (Late Pennsylvanian, Saint-Etienne basin, France). Review of Palaeobotany and Palynology 152, 129-140. DOI 10.1016/j.revpalbo.2008.04.007
Gomankov, A.V. 2009. Pollen evolution in cordaites and early conifers. Paleontological Journal 43, 1245-1252.

DOI 10.1134/S0031030109100062

HARMS, V.L. \& LEISMAN, G.A. 1961. The anatomy and morphology of certain Cordaites leaves. Journal of Paleontology 35, 1041-1064.

HiLton, J. \& BATEMAN, R.M. 2006. Pteridosperms are the backbone of seed-plant phylogeny. Journal of the Torrey Botanical Society 133, 119-168. DOI 10.3159/1095-5674(2006)133[119:PATBOS]2.0.CO;2

HÜBERS, M., BOMFLEUR, B., KRINGS, M. \& KeRP, H. 2011. An Early Carboniferous leaf-colonizing fungus. Neues Jahrbuch für Geologie und Paläontologie, Abhandlungen 261, 77-82. DOI 10.1127/0077-7749/2011/0150

KARLING, J.S. 1977. Chytridiomycetarum Iconographia. An Illustrated and Brief Descriptive Guide to the Chytridiomycetous Genera with a Supplement of the Hyphochytridiomycetes. viii + 414 pp. J. Cramer, Vaduz.

KrINGS, M. 2001. Pilzreste auf und in den Fiedern zweier Pteridospermen aus dem Stefan von Blanzy-Montceau (Zentralfrankreich). Abhandlungen des Staatlichen Museums für Mineralogie und Geologie zu Dresden 46/47, 189-196.

KringS, M., DOTZLER, N., GALTIER, J. \& TAYLOR, T.N. 2009a. Microfungi from the upper Visean (Mississippian) of central France: Chytridiomycota and chytrid-like remains of uncertain affinity. Review of Palaeobotany and Palynology 156, 319-328. DOI 10.1016/j.revpalbo.2009.03.011

Krings, M., DOTZLER, N., TAYLOR, T.N. \& GALTIER, J. 2009b. A Late Pennsylvanian fungal leaf endophyte from GrandCroix, France. Review of Palaeobotany and Palynology 156, 449-453. DOI 10.1016/j.revpalbo.2009.04.010

KringS, M., GALTIER, J., TAYLOR, T.N. \& DOTZLER, N. 2009c. Chytrid-like microfungi in Biscalitheca cf. musata (Zygopteridales) from the Upper Pennsylvanian Grand-Croix cherts (Saint-Etienne Basin, France). Review of Palaeobotany and Palynology 157, 309-316.

DOI 10.1016/j.revpalbo.2009.06.001

KRINGS, M., DOTZLER, N., TAYLOR, T.N. \& GALTIER, J. 2010a. A fungal community in plant tissue from the Lower Coal Measures (Langsettian, Lower Pennsylvanian) of Great Britain. Bulletin of Geosciences 85, 679-690.

DOI 10.3140/bull.geosci.1209

KRINGS, M., DOTZLER, N., TAYLOR, T.N. \& GALTIER, J. 2010 b. Microfungi from the upper Visean (Mississippian) of central France: Structure and development of the sporocarp Mycocarpon cinctum nov. sp. Zitteliana A 50, 127-135.

KRINGS, M., TAYLOR, T.N., GALTIER, J. \& DOTZLER, N. 2010c. Microproblematic endophytes and epiphytes of fern pinnules from the Upper Pennsylvanian of France. Geobios 43, 503-510. DOI 10.1016/j.geobios.2010.02.002

KringS, M., DOtZler, N., GALTIER, J. \& TAYLOR, T.N. 2011. Oldest fossil basidiomycete clamp connections. Mycoscience 52, 18-23. DOI 10.1007/s10267-010-0065-4

LABANDEIRA, C.C. 1998. Early history of arthropod and vascular plant associations. Annual Review of Earth and Planetary Sciences 26, 329-377.

DOI 10.1146/annurev.earth.26.1.329

MARTín-Closas, C. \& GALTIER, J. 2005. Plant taphonomy and paleoecology of Late Pennsylvanian intramontane wetlands in 
the Graissessac-Lodève basin (Languedoc, France). Palaios 20, 249-265.

MÜLLER, A.H. 1982. Über Hyponome fossiler und rezenter Insekten, erster Beitrag. Freiberger Forschungsheft C 366, $7-27$.

Oliver, F.O. 1903. Notes on fossil fungi. New Phytologist 2, 49-53. DOI 10.1111/j.1469-8137.1903.tb05809.x

PETRINI, O. 1991. Fungal endophytes of tree leaves, 179-197. In ANDREWS, J.H. \& HIRANO, S.S. (eds) Microbial Ecology of Leaves. Springer-Verlag, New York.

PRUVOST, P. 1947. Le Stéphanien du bassin houiller de la Loire. Annales de la Société Géologique du Nord 67, 279-295.

Rodriguez, R.J., White, J.F. JR., ARNOLD, E.E. \& REDMAN, R.S. 2009. Fungal endophytes: diversity and functional roles. New Phytologist 182, 314-330. DOI 10.1111/j.1469-8137.2009.02773.x

SHERWOOD-PIKE, M. 1991. Fossils as keys to evolution in fungi. BioSystems 25, 121-129. DOI 10.1016/0303-2647(91)90018-G

ŠIMŮNEK, Z. 2000. Cuticles of Cordaites from the Westphalian, Stephanian and Autunian of the Bohemian Massif (Czech Republic) (a preliminary study). Acta Palaeobotanica 40, 25-34.

ŠIMŮNEK, Z. 2007. New classification of the genus Cordaites from the Carboniferous and Permian of the Bohemian Massif, based on cuticle micromorphology. Acta Musei nationalis Pragae, Series B - historia naturalis 62, 97-210.

ŠIMŮNEK, Z. \& LIBERTÍN, M. 2006. Cordaites schatzlarensis sp. nov. and Samaropsis newberryi (Andrews) Seward from the Westphalian (Carboniferous) of the Žaclér area (Czech Republic). Review of Palaeobotany and Palynology 138, 43-62. DOI 10.1016/j.revpalbo.2005.10.001

Strullu-Derrien, C., Rioult, J.P. \& Strullu, D.G. 2009. Mycorrhizas in Upper Carboniferous Radiculites-type cordaitalean rootlets. New Phytologist 182, 561-564. DOI 10.1111/j.1469-8137.2009.02805.x

Strullu-Derrien, C., Kenrick, P., Rioult, J.P. \& Strullu, D.G. 2011. Evidence of parasitic Oomycetes (Peronosporomycetes) infecting the stem cortex of the Carboniferous seed fern Lyginopteris oldhamia. Proceedings of the Royal Society, Series B 278, 675-680. DOI 10.1098/rspb.2010.1603

TAYLOR, T.N., GALTIER, J. \& AXSMITH, B.J. 1994. Fungi from the Lower Carboniferous of central France. Review of Palaeobotany and Palynology 83, 253-260. DOI 10.1016/0034-6667(94)90073-6

TAYLOR, T.N., REMY, W. \& HASS, H. 1992. Fungi from the Lower Devonian Rhynie chert: Chytridiomycetes. American Journal of Botany 79, 1233-1241. DOI 10.2307/2445050

TAYLOR, T.N., TAYLOR, E.L. \& KRINGS, M. 2009. Paleobotany. The Biology and Evolution of Fossil Plants. xxi +1230 pp. Elsevier/Academic Press Inc., Burlington MA, London, San Diego CA, New York NY.

VETTER, P. 1971. Le Carbonifère supérieur et le Permien du Massif Central, 169-213. In JUNG, J. (ed.) Symposium. Plein-Air Service, Clermont-Ferrand. 